\title{
Serum Cortisol Response in Acute Hypoglycemic Diabetic/Non Diabetic Patients Arriving through Emergency Department - A Comparative Study
}

\author{
Naveen Mohan*, Gireesh Kumar K.P, Ajith Kumar. J, Sreekrishnan T.P, Ajith.V, Bharath Prasad. S, \\ Krupanidhi Karunanithi, Arun Kumar. K, Vishnu Manohar, Nandu.M
}

Department of Emergency Medicine \& Critical Care, Amrita Institute of Medical Sciences \& Research Centre, India
*Corresponding Author: drnaveenmohan@gmail.com

Copyright (C) 2015 by authors, all rights reserved. Authors agree that this article remains permanently open access under the terms of the Creative Commons Attribution License 4.0 International License

\begin{abstract}
Background and objectives: Hypoglycemia in the body is controlled by counter regulatory hormones. Serum cortisol is one among them not subjected to extensive study, in Type 2 diabetes mellitus cases. Cortisol responses among non diabetics and type 1 diabetics have been studied to a certain extent. The primary objective of our study was to identify the serum cortisol levels in hypoglycemic patients with or without type 2 diabetes and to find out the correlation between the mean cortisol responses in the two groups. Methodology: A total population of 51 symptomatic hypoglycemic patients meeting Whipple's criteria were studied in the ER of a medical college hospital at Kochi. Forty patients were diabetic and 11 non diabetic. Previous history, present illness, comorbidities, medical history and reasons for hypoglycemia were considered. Laboratory investigations on RFT, 7 AM serum cortisol and RBS were made and the results analysed applying standard statistical methods and SPSS II software. Results and discussion: Male female ratio in the diabetic and non diabetic groups was 3:1 and 10:1 respectively. Hypoglycemia was more among males, especially in the diabetic group due to decreased food intake $(49 \%)$ or concurrent illness $(51 \%)$, the mean age being 65.7 years in these cases. Hypoglycemia was more frequent in those on sulfonylurea $(61.9 \%)$, and in habitual insulin users $(42.5 \%)$. In non diabetic patients, hypoglycemia was caused by renal failure $(27.27 \%)$, insulinoma( $27.27 \%$ ) or sepsis $(18.18 \%)$. The mean serum cortisol among the diabetic group was subnormal(17.47), and in the non diabetic group it was 28.56. Age, sex, serum creatinine, GCS, period of stay and condition at discharge showed no correlation with serum cortisol levels. RBS, period of stay and condition at discharge showed no correlation with diabetic status. Conclusion: Diabetic patients with acute symptomatic hypoglycemia demonstrated a subnormal serum cortisol response as compared to non diabetic hypoglycemic patients.
\end{abstract}

Keywords Serum Cortisol, Hypoglycemia, Type 2 Diabetes Mellitus, Sulfonylurea, Insulin

\section{Introduction}

Hypoglycemia is a major cause of mortality/morbidity all over the world, drug induced in patients with diabetes, or may be due to other reasons in the non diabetic populations. Glucose homeostasis in the body is maintained by the HPA axis through hormones. Serum cortisol is one among them. Various studies have been made on hypoglycemia among type 1 diabetics and non diabetics, where such information on type 2 diabetes are lacking. Serum cortisol response in type 2 diabetics has not been properly studied. Previous studies have demonstrated that glucose counter regulatory mechanisms are abnormal in insulin treated and non insulin treated type 2 diabetics. Serum cortisol increased in response to prolonged hypoglycemia in normal individuals [1] and in patients with chronic diabetic complications[2]. It limits glucose utilization and enhance hepatic glucose production as per the requirement. In diabetic patients with hypoglycemia, there exists a subnormal response with resultant prolonged hypoglycemia. The objective of this study was to estimate the serum cortisol levels in hypoglycemic diabetic/non diabetic patients after a single cortisol response at the time of hypoglycemia, and to find out the correlation between the mean cortisol responses in both these groups.

\section{Methodology}

A non interventional observational study of patients 
presenting to the ER of a medical college hospital at Kochi with hypoglycemia was undertaken from December 2008 to December 2010. Based on a previous study[3] on the serum cortisol levels in diabetic/non diabetic patients with hypoglycemia, a mean of $2.2 \mathrm{mcg} / \mathrm{dl} \pm 0.5$ was obtained in diabetic cases and a mean of $4 \mathrm{mcg} / \mathrm{dl} \pm 0.7$ was obtained in the non diabetic cases [3]. With $99 \%$ confidence and $10 \%$ allowable error, minimum sample size computed for diabetic patients was 35 whereas for the non diabetic patients, the sample size was 5 .

Though the minimum sample size computed was 35 , and 5 respectively in both these groups, we have selected 42 diabetics and 11 non diabetics for this study. Two patients were eliminated from this group as they violated the inclusion or exclusion criteria on subsequent evaluation. So, the total population subjected to the study was 51 (40 diabetics and 11 non diabetics).

Patients with symptoms of hypoglycemia later on confirmed by blood glucose value less than $60 \mathrm{mg} / \mathrm{dl}$ (as per ADA 2010 guidelines), showing relief of symptoms when plasma glucose concentration was brought to normal, were included in the study. Patients on steroid therapy and those having adrenal insufficiency were excluded.

Each selected patient was subjected to thorough examination. History regarding previous illness, present illness, co morbidities, medications, diabetic history and reasons for hypoglycemia were collected. Laboratory investigations on RFT, 7 am serum cortisol and RBS were made in the hospital laboratory.

For the comparison of values of different variables on an average between the two groups, and for testing the statistical significance of the values of the variables such as serum cortisol, RBS, period of stay, age group, sex distribution, GCS, co morbidities, serum creatinine level and condition at discharge, Wilcoxon rank sum test was applied because of the small sample size in one of the groups and high variation in the values in both these groups. Probability values less than 0.05 was considered as statistically significant. Statistical analysis was done using SPSS 2 software..

\section{Results}

The study population consisted of 51 patients (diabetic and non diabetic), with hypoglycemia, satisfying the Whipple's criteria. $78 \%$ were diabetic and $22 \%$ non diabetic, comprising both males and females[Table 1].

Sex distribution in diabetic an non diabetic patients (both gender) showed no correlation with each other, as the $p$ value obtained was not significant $(\mathrm{p}=0.418$ ).

We obtained a mean age of 65.7 in the diabetic group and 45.36 in the non diabetic group[Table 1].

Drowsiness, sweating, general weakness and seizures were the common symptoms in most cases, whereas some of the patients were asymptomatic [Table 1].

No significant relationship was noticed between diabetic and non diabetic patients as far as presenting symptoms are concerned.

Table 1. Characteristics of the population( $\mathrm{n}=51)$

\begin{tabular}{|c|c|c|c|c|c|c|}
\hline & Characteristics & Diabetic $(\mathrm{n}=40)$ & Percentage & Non diabetic & Percentage & $P$ value \\
\hline 1 & Subjects & 40 & 78 & 11 & 22 & \\
\hline 2 & \multicolumn{5}{|c|}{ Sex } & \multirow{5}{*}{$\begin{array}{c}0.418 \\
\text { Not } \\
\text { significant }\end{array}$} \\
\hline & Male & 30 & 75 & 10 & 90.9 & \\
\hline & Female & 10 & 25 & 1 & 9.1 & \\
\hline & Total & 40 & 100 & 11 & 100 & \\
\hline & Male:Female & $3: 1$ & & $10: 1$ & & \\
\hline \multirow[t]{2}{*}{3} & \multicolumn{5}{|c|}{ Age(years) } & \\
\hline & Mean & 65.7 & & 45.36 & & \\
\hline 4 & \multicolumn{5}{|c|}{ Presenting symptoms } & \multirow{5}{*}{$\begin{array}{c}0.866 \\
\text { Not } \\
\text { significant }\end{array}$} \\
\hline & Drowsiness \& sweating & 16 & 40 & 4 & 36.36 & \\
\hline & General weakness \& seizures & 16 & 40 & 5 & 45.45 & \\
\hline & Others & 8 & 20 & 2 & 18.18 & \\
\hline & Total & 40 & 100 & 11 & 99.99 & \\
\hline
\end{tabular}


Table 2. Distribution of hypoglycemic incidence among patients on diet control, oral hypoglycemic agents and insulin $(n=40)$

\begin{tabular}{|c|c|c|}
\hline Diet control & 2 & $5 \%$ \\
\hline \multicolumn{3}{|c|}{ Medications } \\
\hline Only OHA & 8 & $20 \%$ \\
\hline Only insulin & 17 & $42.5 \%$ \\
\hline OHA+insulin & 13 & $32.5 \%$ \\
\hline Total & $\mathbf{4 0}$ & $\mathbf{1 0 0 \%}$ \\
\hline
\end{tabular}

Hypoglycemic incidence was more in those patients exclusively on insulin (42.5\%) as compared with patients on $\mathrm{OHA}(20 \%)$ or OHA plus insulin(32.5\%) [Table 2].

Table 3. Profile of comorbidities in diabetic and non diabetic cases $(n=51)$

\begin{tabular}{|c|c|c|}
\hline DM & 13 & $25.5 \%$ \\
\hline DM/DLP & 2 & $3.9 \%$ \\
\hline DM/HTN/DLP & 12 & $23.5 \%$ \\
\hline DM/HTN & 13 & $25.5 \%$ \\
\hline DLP & 4 & $7.8 \%$ \\
\hline HTN/DLP & 2 & $3.9 \%$ \\
\hline HTN & 2 & $3.9 \%$ \\
\hline No comorbidities & 3 & $5.9 \%$ \\
\hline Total & $\mathbf{5 1}$ & $\mathbf{1 0 0 \%}$ \\
\hline
\end{tabular}

The major comorbidities which contributed to hypoglycemia were diabetes mellitus alone(25.5\%), diabetes mellitus/ hypertension combination (25.5\%) and diabetes/hypertension/dyslipidemia combination $(23.5 \%)$ [Table 3].

Table 4. Reason for hypoglycemia in diabetic and non diabetic $\operatorname{cases}(\mathrm{n}=51)$

\begin{tabular}{|c|c|c|}
\hline Decreased food intake & 25 & $49 \%$ \\
\hline Concurrent illness & 26 & $51 \%$ \\
\hline Total & $\mathbf{5 1}$ & $\mathbf{1 0 0} \%$ \\
\hline
\end{tabular}

Table 5. Causes of hypoglycemia among non diabetic patients $(\mathrm{n}=11)$

\begin{tabular}{|c|c|c|}
\hline Liver failure & 1 & $9.09 \%$ \\
\hline Cardiac failure & 1 & $9.09 \%$ \\
\hline Renal failure & 3 & $27.27 \%$ \\
\hline Sepsis & 2 & $18.18 \%$ \\
\hline Hypopituitarism & 1 & $9.09 \%$ \\
\hline Insulinoma & 3 & $27.27 \%$ \\
\hline Total & $\mathbf{1 1}$ & $\mathbf{1 0 0 \%}$ \\
\hline
\end{tabular}

Decreased food intake/ concurrent illness caused hypoglycemia in the diabetic group[Table 4], whereas insulinoma/diseases caused hypoglycemia in the non diabetic group[Table 5].
Table 6. Comparison of frequency of hypoglycemia among OHA

\begin{tabular}{|c|c|c|}
\hline Metformin & 8 & $38.09 \%$ \\
\hline Sulfonylureas & 13 & $61.90 \%$ \\
\hline Total & $\mathbf{2 1}$ & $\mathbf{1 0 0 \%}$ \\
\hline
\end{tabular}

The intake of drugs like sulfonylure caused higher incidence of hypoglycemia in the diabetic group [Table 6].

Table 7. Diabetic status and age distribution

\begin{tabular}{|c|c|c|c|c|c|}
\hline Age(years) & Diabetic & $\%$ & Non diabetic & $\%$ & P value \\
\hline 20 to 59 & 12 & 30 & 10 & 90.9 & \multirow{2}{<}{$<0.001$} \\
\cline { 2 - 5 } 60 \& above & 28 & 70 & 1 & 9.1 & Significant \\
\hline Total & $\mathbf{4 0}$ & $\mathbf{1 0 0}$ & $\mathbf{1 1}$ & $\mathbf{1 0 0}$ & \\
\hline
\end{tabular}

The incidence of hypoglycemia increased with age showing a significant correlation in the diabetic group, and the maximum number of patients were in the age group 60 and above $(70 \%)$. The maximum number of patients with hypoglycemia in the non diabetic group were below 60 years $(90.9 \%)$ [Table 7$]$.

Table 8. Mean serum cortisol response in diabetic and non diabetic patients with hypoglycemia

\begin{tabular}{|c|c|c|c|}
\hline Serum cortisol & Diabetic $(\mathrm{n}=40)$ & $\begin{array}{c}\text { Non } \\
\text { diabetic }(\mathrm{n}=11)\end{array}$ & p value \\
\hline Mean & 17.47 & 28.56 & \multirow{2}{*}{$<0.001$} \\
$\begin{array}{c}\text { Standard } \\
\text { deviation }\end{array}$ & 8.969 & 9.487 & Significant \\
\cline { 1 - 3 } Median & 15 & 31 & \\
\hline
\end{tabular}

A mean cortisol value of $17.47 \pm 8.9 \mathrm{mcg} / \mathrm{dl}$ was obtained in the diabetic group, as against $28.56 \pm 9.48$ in the non diabetic group[Table 8], showing statistically significant correlation. Based on a previous study[1], the cut off value for serum cortisol was taken as $18 \mathrm{mcg} / \mathrm{dL}$. $67.5 \%$ (27) patients in the diabetic group exhibited a subnormal response, and $36.5 \%$ (13) showed a normal response, proving that serum cortisol response got impaired in the diabetic group[Table 13].

Table 9. Diabetic status and RBS values(mg/dL)

\begin{tabular}{|c|c|c|c|c|c|}
\hline $\begin{array}{c}\text { Diabetic } \\
\text { status }\end{array}$ & Number & $\begin{array}{c}\text { Mean } \\
\text { RBS }\end{array}$ & $\begin{array}{l}\text { Standard } \\
\text { deviation }\end{array}$ & Median & $\mathrm{P}$ value \\
\hline Diabetic & 40 & 42.69 & 11.799 & 44 & \multirow{2}{*}{$\begin{array}{c}0.869 \\
\text { Not } \\
\text { significant }\end{array}$} \\
\hline $\begin{array}{c}\text { Non } \\
\text { diabetic }\end{array}$ & 11 & 42.18 & 8.727 & 40 & \\
\hline Total & 51 & & & & \\
\hline
\end{tabular}

Table 10. Diabetic status and period of stay

\begin{tabular}{|c|c|c|c|c|c|}
\hline $\begin{array}{c}\text { Diabetic } \\
\text { status }\end{array}$ & Number & $\begin{array}{c}\text { Mean } \\
\text { period } \\
\text { of stay }\end{array}$ & $\begin{array}{c}\text { Standard } \\
\text { deviation }\end{array}$ & Median & P value \\
\hline Diabetic & 40 & 5.53 & 8.083 & 3 & $\begin{array}{c}0.140 \\
\text { Not } \\
\text { significant }\end{array}$ \\
\hline $\begin{array}{c}\text { Non } \\
\text { diabetic }\end{array}$ & 11 & 6.27 & 4.221 & 5 & \\
\hline Total & $\mathbf{5 1}$ & & & & \\
\hline
\end{tabular}


Table 11. Serum cortisol and age distribution

\begin{tabular}{|c|c|c|c|c|c|}
\hline Age(years) & Number & Mean serum cortisol level & Standard deviation & Median & $\mathrm{P}$ value \\
\hline 20 to 59 & 22 & 20.31 & 11.352 & 22 & \multirow{2}{*}{$\begin{array}{c}0.785 \\
\text { Not significant }\end{array}$} \\
\hline 60 and above & 20 & 19.52 & 9.229 & 17 & \\
\hline
\end{tabular}

Table 12. Serum cortisol level and sex distribution $(n=51)$

\begin{tabular}{|c|c|c|c|}
\hline Serum cortisol & Male $(\mathrm{n}=40)$ & Female $(\mathrm{n}=11)$ & P value \\
\hline Mean & 20.25 & 18.44 & 0.801 \\
Not significant \\
\hline
\end{tabular}

Table 13. Serum cortisol response in diabetic patients $(\mathrm{n}=40)$

\begin{tabular}{|c|c|c|}
\hline Subnormal $(<18 \mathrm{mcg} / \mathrm{dl})$ & 27 & $67.5 \%$ \\
\hline Normal $(>18 \mathrm{mcg} / \mathrm{dl})$ & 13 & $32.5 \%$ \\
\hline Total & $\mathbf{4 0}$ & $\mathbf{1 0 0} \%$ \\
\hline
\end{tabular}

Table 14. Serum cortisol and GCS

\begin{tabular}{|c|c|c|c|c|c|}
\hline GCS & Number & Mean serum cortisol level & Standard deviation & Median & P value \\
\hline Mild(13 to 15) & 39 & 19.17 & 11.062 & 15 & 0.331 \\
Moderate and severe (3 to 12) & 12 & 21.75 & 7.606 & 22 & Not significant \\
\hline
\end{tabular}

Table 15. Serum cortisol and creatinine level

\begin{tabular}{|c|c|c|c|c|c|}
\hline Creatinine $(\mathrm{mg} / \mathrm{dL})$ & Number $(\mathrm{n}=51)$ & Mean serum cortisol level $(\mathrm{mcg} / \mathrm{dL})$ & Standard deviation & Median & P value \\
\hline$<1.4$ & 42 & 19.91 & 9.865 & 19 & 0.551 \\
& $>1.4$ & 19.63 & 11.772 & 14.70 & Not significant \\
\hline
\end{tabular}

Table 16. Serum cortisol and period of stay

\begin{tabular}{|c|c|c|c|c|c|}
\hline Serum cortisol(mcg/dL) & Number(n=51) & Mean serum cortisol level(mcg/dL) & Standard deviation & Median & P value \\
\hline$<18 \mathrm{mcg} / \mathrm{dL}$ & 28 & 6.36 & 8.586 & 4.50 & 0.407 \\
\cline { 1 - 1 } & 23 & 4.87 & 5.691 & 3.00 & Not significant \\
\hline
\end{tabular}

Table 17. Serum cortisol and condition at discharge

\begin{tabular}{|c|c|c|c|c|c|}
\hline Serum cortisol $(\mathrm{mcg} / \mathrm{dL})$ & Number $(\mathrm{n}=51)$ & Mean serum cortisol level $(\mathrm{mcg} / \mathrm{dL})$ & Standard deviation & Median & P value \\
\hline Better & 46 & 19.84 & 10.220 & 17.30 & 0.966 \\
Expired & 6 & 20.02 & 10.028 & 18.10 & Not significant \\
\hline
\end{tabular}

Serum cortisol levels showed no significant correlation with age[Table 11], sex[Table 12], GCS[Table 14], serum creatinine[Table 15], period of stay[Table 16] or condition at discharge[Table 17]. RBS[Table 9] and period of stay[Table 10] showed no correlation with diabetic status.

\section{Discussion}

The study population consisted of 40 diabetic and 11 non diabetic patients with hypoglycemia satisfying the Whipple's criteria, comprising both males and females. An increased incidence of hypoglycemia was noticed among the males, probably due to decreased drug compliance or increased incidence of concurrent illness.

The mean age for diabetic patients was 65.7 years and for non diabetic patients 45.36 years. The incidence of hypoglycemia increased with age in the diabetic population and the maximum number $(70 \%)$ of hypoglycemic patients belonged to the age group 60 years and above. Various comorbidities other than diabetes might have predisposed the elderly to hypoglycemia also. The mean age obtained as per a previous study was $46 \pm 3$ and $42 \pm 3$ respectively in each group.

The patients presented themselves with neurogenic or neuroglycopenic symptoms of hypoglycemia. Majority of the patients came with drowsiness and sweating $(40 \%)$, general weakness and seizures( $40 \%)$. Some of the patients were asymptomatic, probably due to hypoglycemia unawareness resultant to sympatho adrenal, sympathetic neural responses to a given degree of hypoglycemia caused by recent antecedent hypoglycemia, prior exercise, or sleep 
in patients with diabetes $[4,1]$.

The reason for hypoglycemia in the diabetic group was decreased food intake(49\%), as well as concurrent illness $(51 \%)$. In the non diabetic group, the causes were insulinoma and concurrent illness, and mainly due to renal failure (27.3\%).

Some of the diabetic patients had dyslipidemia and hypotension when majority of the population had diabetes, hypertension and dyslipidemia (23.5\%).

Among the patients on OHA, those taking sulfonylurea had a higher prevalence of hypoglycemia(61.9\%). High incidence of hypoglycemia was obtained in patients exclusively on subcutaneous insulin(42\%). Improper use or overdose of insulin might have caused this phenomenon. The overall event rate for severe hypoglycemia in insulin treated type 2 diabetics was approximately $30 \%$ of that of type 1 diabetes, as per earlier studies [5]. The prevalence rate of mild hypoglycemic symptoms has been reported as 16 to $20 \%$ in patients using sulfonylurea agents, and 30 to $50 \%$ in patients treated with subcutaneous insulin [6].

Regarding serum cortisol levels among hypoglycemic diabetic/non diabetic patients arriving through the ER, no studies hitherto have attempted to adjudge the serum cortisol response after a single blood test at the time of a hypoglycemic incidence. We have done this, and obtained mean serum cortisol values of $17.47 \pm 8.9 \mathrm{mcg} / \mathrm{dl}$ and $28.56 \pm 9.48 \mathrm{mcg} / \mathrm{dl}$ respectively, in the diabetic vs non diabetic population. In a previous study on hyperinsulinemic hypoglycemia, mean serum cortisol value obtained in the diabetic group was $2.2 \pm 0.5 \mathrm{mcg} / \mathrm{dl}$ as against $4 \pm 0.7 \mathrm{mcg} / \mathrm{dl}$ ( $p$ value $<0.05$ ) in the non diabetic group[3]. Both studies revealed a decreased cortisol response among the hypoglycemic diabetic patients as compared to the non diabetic patients with hypoglycemia.

Age and sex distribution showed no correlation with serum cortisol levels.

Based on a previous study[7], the cut off value for serum cortisol was taken as $18 \mathrm{mcg} / \mathrm{dl}$. It was found that about $67.5 \%(27)$ of the diabetic patients were having a subnormal response whereas $32,5 \%(13)$ was having a normal response, clearly indicating that serum cortisol response got impaired in the diabetic patients.

No significant correlation was obtained between GCS and serum cortisol levels.

Long standing diabetic patients are prone to diabetic nephropathy, depending on the duration of the illness. So, serum cortisol levels were correlated with serum creatinine levels, but no significant correlation was obtained between the two. Similarly, the period of stay and the condition at discharge (survived/expired) showed no correlation with serum cortisol levels.

\section{Limitations}

Cortisol secretion increases on physical and psychological stress, both of which were not taken into consideration in this study. Cortisol levels show diurnal variation, with peak levels during early morning and low levels during evening hours. Even though 7 AM cortisol was taken for study, the levels depend on the circadian sleep pattern of each patient, which can be a major confounding factor in the judgement. Immunoassays in the institution measured total serum cortisol, most of which exist in a protein bound state. Unbound cortisol is the biologically active product. Hence factors that raise the levels of binding proteins can show falsely elevated cortisol levels in the blood.

\section{Suggestions and Recommendations}

Further studies involving large populations of hypoglycemic diabetic/non diabetic patients are required to establish a cut off value for diagnosing hypocortisolism in both these groups.

The reason for the subnormal cortisol response among the hypoglycemic diabetic patients is a curious finding, requiring further investigation. The clinical significance of reduced cortisol levels among the diabetic group and the role of steroids in such patients have to be subjected to further studies. Studies on serum cortisol levels in both these groups at different intervals have to be undertaken to ascertain whether the subnormal response seen among the diabetic group was showing a uniform pattern throughout the day.

\section{Conclusions}

Hypoglycemia was more common among the males and the elderly diabetic population, caused due to decreased food intake (49\%) and concurrent illness $(51 \%)$. The incidence of hypoglycemia was more in sulfonyl urea takers and habitual subcutaneous insulin users. Hypoglycemic incidence increased with age in the diabetic group, the majority of the patients belonged to the age group 60 and above. Among the non diabetic group, the maximum number of patients were below 60 years. A subnormal serum cortisol response was clearly visible among hypoglycemic diabetic patients, with a mean cortisol level of $17.47 \pm 8.9 \mathrm{mcg} / \mathrm{dl}$, as against a response of $28.56 \pm 9.48 \mathrm{mcg} / \mathrm{dl}$ in the non diabetic hypoglycemic patients. Serum cortisol levels showed no correlation with age, sex, serum creatinine, GCS, period of stay and condition at discharge. Similarly RBS, period of stay and condition at discharge showed no correlation with the diabetic status.

\section{Acknowledgements}

1. All the staff of Department of Emergency Medicine and Critical Care, Amrita Institute of Medical Sciences, Kochi.

2. Department of Biostatistics, Amrita Institute of Medical Sciences, Kochi. 
3. Department of Endocrinology, Amrita Institute of Medical Sciences, Kochi.

\section{REFERENCES}

[1] Cryer, PE. Hypoglycemia in diabetes. Pathophysiology, prevalence, and prevention. America Diabetes Association, Alexandri VA, 2009.

[2] Workgroup on Hypoglycemia, American Diabetes Association. Defining and reporting hypoglycemia in diabetes: a report from the American Diabetes Association Workgroup on Hypoglycemia. Diabetes Care $2005 ; 2005 ; 28: 1245$

[3] Bolli GB, Tsalikian E, Haymond MW, Cryer PE, Gerich JE. Defective glucose counter regulation after subcutaneous insulin in noninsulin-dependent diabetes mellitus.
Paradoxical suppression of glucose utilization and lack of compensatory increase in glucose production, roles of insulin resistance, abnormal neuroendocrine responses, and islet paracrine interactions. Journal of Clinical Investigation. 1984;73(6):1532-1541.

[4] Cryer, PE, Axelrod, Grossman, AB, et al. Evaluation and management of adult hypoglycemic disorders: an Endocrine Society Clinical Practice Guideline. J Clin Endocrinol Metab 2009;94:709

[5] Donnelly, LA, Morris, AD, Frier, BM, et al. Frequency and predictors of hypoglycemia in Type 1 and insulin treated Type 2 diabetes: a population based study. Diabet Med 2005;22:749.

[6] Marks, V, Teale,JD. Drug induced hypoglycemia. Endocrinol Metab Clin North Am 1999;28:555.

[7] Schultz CH, Rivers EP, Feldkamp CS, et al. 1993. A characterization of hypothalamic pituitary adrenal axis function during and after human cardiac arrest. Crit Care Med. $21: 1339-1347$. 